\title{
40 år gamle kvinner som bruker hormonregimer - sunne utvalg eller risikogrupper?
}

\author{
Resultater fra helseundersøkelser i 11 norske fylker 1997-99
}

\author{
Sidsel Graff-Iversen \\ Statens helseundersøkelser, Postboks 8155 Dep, 0033 Oslo \\ Telefon: 22242154 Telefax: 22242101 E-post: Sidsel.Graff-Iversen@shus.no
}

\begin{abstract}
SAMMENDRAG
Formålet med denne artikkelen var å studere brukerne av kombinerte antikonsepsjonsmidler, regimer med progesteron alene og østrogensubstitusjon blant norske 40-åringer. Var det først og fremst lavrisikogrupper - friske og røykfrie kvinner - som brukte p-piller av kombinasjonstype, slik gjeldende anbefalinger råder til? Var progesteronbrukerne et utvalg av særlig helsebevisste kvinner? Hvor utbredt var bruken av østrogen i denne aldersgruppen? Var det tegn til at østrogenbrukerne er en "healthy selection", slik utenlandske studier har vist?

Materialet er fra 40-åringsundersøkelser i 11 norske fylker i tiden 1997-99. Resultatene viser at 3,5\% av kvinnene brukte kombinerte antikonseptiva og at disse utgjorde et "sunt utvalg" med lave andeler røykere og god helse. De 9,4\% av kvinnene som brukte progesteron alene, skilte seg derimot lite fra premenopausale kvinner uten hormonbruk. De 2,4\% av kvinnene som brukte østrogen, hadde mindre god helse, høyere andel røykere og lavere utdanningsnivå, sammenlignet med premenopausale kvinner. Men sammenligning innen gruppen av post- og perimenopausale kvinner viste ingen vesentlig forskjell mellom østrogenbrukerne og andre. Resultatet fra den første kontrollerte studien av østrogen og hjertesykdom kom i 1998, men førte ikke til noen påviselig forskjell i seleksjonen til østrogenbruk fra 1997 til 1999.

Konklusjonen er at kvinnene som brukte kombinerte antikonseptiva i 40-årsalderen var en "sunn seleksjon" i tråd med det som blir anbefalt, mens de som brukte progesteron alene skilte seg lite ut fra kvinner som ikke brukte hormoner. Kvinner som brukte østrogen i denne unge alderen, sto fram som en helsemessig risikogruppe i materialet som helhet, men skilte seg lite ut fra andre antatt post- eller perimenopausale kvinner i 40-årsalderen.
\end{abstract}

\section{Graff-Iversen, S. 40-year old female sex hormone users: healthy selections or risk groups? Results from health surveys in 11 Norwegian counties 1997-99. Nor J Epidemiol 2001; 11 (1): 73-79.}

\section{ENGLISH SUMMARY}

The aim was to study the use of female sex hormone regimens by health and health behavior in middle-aged women from the general population. Did current users of combined hormonal contraceptives represent a healthy selection, in line with clinical guidelines? Did the users of estrogen replacement therapy (ERT) represent a selection with low cardiovascular risk, as studies in other countries have suggested? And if so, did the selection change during 1997 to 1999 , as might be suggested from the results from a controlled study of ERT and coronary heart disease, which was published in 1998 ?

During 1997-99 all inhabitants aged 40-42 years in 11 Norwegian counties were invited to a health survey. Of 54,296 women invited, 3,4730 (64\%) attended, and 34,284 gave complete information on menstruation and the use of sex hormones. A minority of $3.5 \%$ of the women used combined hormonal contraceptives. Among those the health was better and the prevalence of smoking was lower, in spite of a lower level of education, compared with the premenopausal non-users of hormones. A total of $9.4 \%$ used progestin alone, and this group was not different from the premenopausal non-users. A total of 2594 women, $7.6 \%$, reported menopause, possible menopause, irregular menstruation periods or use of ERT. All of these groups were characterized by less good health and well-being, high prevalences of smoking, and lower educational levels, compared with premenopausal women. But those using ERT did not differ to an essential degree from the other post- or perimenopausal groups. The selection to the use of estrogen showed a similar pattern in 1997, 1998 and in 1999.

In conclusion, the Norwegian women aged 40-42 using combined hormonal contraceptives during 1997-99 were a healthy selection, in line with the current clinical guidelines. Those using ERT represented a less healthy selection in the population, but did not differ from other post- or perimenopausal groups on their age. 


\section{INNLEDNING}

Helsemessig risiko ved bruk av hormonell antikonsepsjon og østrogensubstitusjon avhenger av arv, helse og levevaner hos brukerne, i tillegg til hva preparatene betyr i seg selv $(1,2)$. Litteraturen har gjennom mange år konkludert med at kombinerte antikonseptiva gir en viss økning av relativ risiko for venøs trombose og annen hjerte- og karsykdom, og det anbefales en tilpasset forskrivingspraksis med seleksjon av yngre, friske og røykfrie kvinner (3-5). Likevel viste norske helseundersøkelser i 1980-årene at brukere over 40 års alder skilte seg ut med høy andel røykere (6). Fortsatt røyker $32 \%$ av norske kvinner, noe som gjør at denne problemstillingen er mer aktuell hos oss enn i de fleste andre vestlige industriland (7). Bruk av progesteron alene har vært ansett som mindre sikker prevensjon, men trygg i bruk når det gjelder risiko for sykdom, og det har vært liten interesse for brukernes bakgrunn. Det kan tenkes at særlig helsebevisste kvinner er i flertall. Men også kvinner som er frarådd å bruke kombinasjonspille, eller på ulike grunnlag har blødningsforstyrrelser, kan tenkes å prege gruppen.

Situasjonen er en helt annen når det gjelder bruk av østrogen i overgangsalderen. Her har interessen for brukernes bakgrunn vært stor, spesielt etter at observasjonsstudier viste $35-45 \%$ reduksjon av dødeligheten hos østrogenbrukere sammenlignet med andre kvinner (8). Flere studier ga holdepunkt for at sunne kvinner i øvre samfunnslag var overrepresentert blant brukerne. Den sosiale skjevheten gjaldt så vel kvinnenes egen etterspørsel som legenes seleksjon ved forskriving, og i tillegg kom seleksjonen av friske kvinner til langvarig bruk (2,9-11). En norsk studie av kvinner som deltok i helseundersøkelser i 1980-årene fant imidlertid høy prevalens av røyking og ikke lavere prevalens av risikofaktorer for hjerte- og karsykdom hos østrogenbrukerne enn hos andre kvinner (12). I tråd med dette har norske forskere funnet at det i 1990-92 ikke var noen forskjell i østrogenbruk mellom utdanningsgrupper (13).

Det kan være mange grunner til at seleksjonen til bruk av farmakologiske regimer varierer geografisk og over tid. Seleksjonen vil påvirkes av kvinnenes sosiale og økonomiske stilling, av holdninger og verdier, av utviklingen av nye preparater, kunnskapsgrunnlaget om effekter og anbefalingene som gis fra faglige autoriteter. Anbefalingene om antikonsepsjon er ikke vesentlig endret de siste årene. I Norsk legemiddelhåndbok for 1998-99 er "storrøykere over 35 år" nevnt under kontraindikasjoner og forsiktighetsregler i forhold til bruk av p-pille, mens bare leversykdom nevnes i forbindelse med progesteron (14). Når det gjelder hormontilskudd i overgangsalderen viste en undersøkelse fra begynnelsen av 1990-årene at legene var i ferd med å bli mer liberale med forskriving, men fortsatt var tilbakeholdne når det gjaldt røykere og kvinner med risiko for hjerte- og karsykdom (15). I en lederomtale ble det understreket at østrogen reduserer risikoen for hjerte- og karsykdom uansett røykevaner (16). I 1996 konkluderte en svensk utredning med at kvinner med tidlig menopause burde tilbys østrogen (8). Samlet tilsier disse anbefalingene ikke at 40åringene som brukte østrogen i 1997-99 skulle være en spesielt sunn seleksjon.

I 1998 kom resultatet av en kontrollert studie av østrogensubstitusjon som sekundær forebygging ved koronar hjertesykdom (17). Alt i alt var det ingen redusert sykelighet og dødelighet knyttet til østrogen etter 4,1 års oppfølging. En initial økt sykelighet i østrogen-gruppen ble avløst av bedre resultater ved lengre tids bruk. Denne publikasjonen førte til at leger ble frarådet å starte behandling med østrogen hvis formålet var å forebygge hjerte- og karsykdom (17). Men studien førte ikke til noen generell advarsel mot østrogen eller råd om seponering (14,17-19).

De viktigste spørsmålene i denne artikkelen er:

1. Var 40 år gamle norske kvinner som brukte kombinerte antikonseptiva i slutten av 1990-årene en seleksjon av ikke-røykende kvinner med lav risiko for hjerte- og karsykdom, slik anbefalingene tilsier?

2. Var norske kvinner som alt i 40 års alder brukte østrogensubstitusjon en "sunn seleksjon", slik utenlandske studier har vist?

3. Var det forskjell fra 1997 til 1999 med hensyn til røyking og andre risikofaktorer for hjerte- og karsykdom hos østrogenbrukerne?

\section{METODE OG MATERIALE}

Fra høsten 1997 til utgangen av 1999 ble ialt 54296 kvinner født mellom 1955 og 1960, bosatt i 11 norske fylker, invitert til helseundersøkelse som deltagere i 40-åringsprogrammet til Statens helseundersøkelser. Opplegget bygget på en modell fra hjerte- og karundersøkelsene i 1970- og 1980-årene $(20,21)$. Alle deltagerne var i alder 40-42 år i kalenderåret undersøkelsen startet i deres fylke. I alt deltok 34730 av de inviterte (64\%). Men 265 spørreskjemaer ble ekskludert på grunn av manglende svar på spørsmål om menstruasjonen, og ytterligere 181 eksklusjoner skyldes inkonsistente svar på spørsmål om hormonbruk. Dette ga et materiale på 34284 kvinner.

Spørsmålene om menstruasjonsforhold og hormonbruk ble innført i 1985 og hadde form av intervju de første årene. Fra høsten 1997 fikk "kvinnespørsmålene" plass på hovedspørreskjemaet som deltagerne fikk tilsendt på forhånd og tok med seg i utfylt stand til undersøkelsen. De fleste spørsmålene gjaldt helseforhold som generell helse, røyking, mosjon, kosthold, nærmere bestemte helseplager og utdanning. "Kvinnespørsmålene" gjaldt menarche, hvorvidt menstruasjonen fremdeles var regelmessig og årsakene til at den eventuelt hadde opphørt eller ikke var regelmessig. Videre var det spørsmål om fødsler, amming og nåværende 
bruk av p-piller, minipiller, vanlig spiral, hormonspiral, østrogen og progesteron. Kvinnene ble bedt å fylle ut navn på de preparatene de for tiden brukte og hvor lenge de hadde brukt preparatet.

Høyde, vekt og midjeomkrets ble målt med lette klær på og avrundet til nærmeste hele centimeter og $0,5 \mathrm{~kg}$. Det ble også tatt blodtrykk og blodprøve til analyser i serum, og resultater av dette blir ikke presentert her.

Forskjellene etter menopausal status og typer av hormonregimer er i dette arbeidet studert ut fra visse sosiale indikatorer (utdanning, sivilstand og husarbeid i hjemmet som hovedyrke), antropometriske mål, selvrapportert generell helse og hjertesykdom i familien, røyking, visse kostvaner og mosjon.

Uregelmessig menstruasjon var presisert på spørreskjemaet som "helt uregelmessig med svært lange eller svært korte perioder". Menopause etter behandling betyr at "menstruasjonen sluttet etter underlivsoperasjon, strålebehandling eller cellegift". Mulig menopause dekker opplysningen om at kvinnen er "usikker på om mentruasjonen har sluttet (mulig overgangsalder)", og spontan menopause betyr at menstruasjonen "sluttet av seg selv for minst 6 måneder siden". Disse blir presentert hver for seg i beskrivelsen av tverrsnittsmaterialet. Sammen med østrogenbrukerne blir de i det følgende kalt "antatt post- eller perimenopausale". Trolig er ingen av disse gruppene homogene hva gjelder ovarialfunksjon.

Ved hjelp av logistisk regresjon med trinnvis eksklusjon av faktorer som ikke møter kriteriet $\mathrm{p}<0,05$ (Logistic regression, SPSS) belyses samvariasjon mellom hormonbruk som avhengig variabel og en rekke uavhengige variabler. Her er alder, utdanning (allmennfag i videregående skole eller høyere utdanning), daglig røyking, hard trim i fritiden (slik at man blir svett eller andpusten minst en gang i uka), overvekt (KMI lik eller over $27 \mathrm{~kg} / \mathrm{m}^{2}$ ), generell helse (god eller svært god versus ikke helt god eller dårlig), brystsmerter ved anstrengelse, muskel- og leddsmerter av minst tre måneders varighet siste år, egen sykdom (hjerte- og karsykdom, høyt blodtrykk eller sukkersyke), hjertesykdom hos foreldre eller søsken, depresjon (en god del eller svært mye de siste to ukene) og daglig bruk av frukt lagt inn (22). Bortsett fra alder er de uavhengige variablene dikotome.

Kvinnene som brukte kombinert antikonsepsjon eller progesteron alene er sammenlignet med kvinner som rapporterte spontan, regelmessig menstruasjon og ikke brukte hormoner, og antas å være premenopausale. I disse analysene ble gravide og kvinner med amenorrè etter fødsel eller primær amenorrè ekskludert.

De som brukte østrogensubstitusjon, er sammenlignet med kvinner som oppga at menstruasjonen hadde opphørt eller var svært uregelmessig og som ikke brukte hormoner. Dette ble gjort separat for dem som ble undersøkt i 1997, i 1998 og i 1999. Dessuten ble analysen utført i materialet som helhet, med alle grupper inkludert og østrogenbruk som avhengig variabel. Det ble også gjort en analyse i hele materialet med antatt post- eller perimenopausal status, østrogenbruk inkludert, som avhengig variabel.

\section{RESULTATER}

Tabell 1 gir en oversikt over helsemessige forhold, levevaner og sosiale forhold i de ulike gruppene. Alder ved menarche var i gjennomsnitt 13,1 år, med spredning fra 12,8 til 13,2 år mellom gruppene i tabellen, og antall barn var i gjennomsnitt 2,2, med spredning fra 2,0 til 2,4. I alt 12 kvinner rapporterte primær amenorré og ingen bruk av hormoner, og for disse er resultatene ikke vist.

Tabell 1 viser at de fleste kvinnene, 78,5\%, oppga å ha regelmessig, spontan menstruasjon uten hormonbruk. Det mest vanlig brukte hormonregimet var progesteron alene, og dette ble benyttet av 9,4\% av kvinnene. Av i alt 3225 progesteronbrukerne brukte 2496 kvinner intrauterin levonorgestrel (hormonspiral). I alt 7276 kvinner oppga bruk av vanlig kobberspiral, og de fleste av disse $(n=6995)$ oppga regelmessig, spontan menstruasjon.

I alt 2594 kvinner, 7,6\% av materialet totalt, rapporterte om opphørt eller svært uregelmessig menstruasjon eller om bruk av østrogen. Kirurgisk inngrep eller annen medisinsk behandling var vanligste årsak til opphør av menstruasjonen. Av de i alt 982 kvinner som hadde mistet menstruasjonen på denne måten, brukte 220 et østrogenholdig regime, mens 11 brukte progesteron alene og 747 kvinner ikke brukte hormoner.

\section{De som brukte kombinerte antikonseptiva}

I alt 3,5\% av kvinnene brukte kombinerte antikonseptiva. Som vist i Tabell 1, hadde disse som gruppe god helse, få helseplager og lav andel røykere, etter norske forhold. I alt 18 brukere ga rapport om uregelmessig eller opphørt menstruasjon, 4 om graviditet og $11 \mathrm{om}$ amenorré etter fødsel, mens de øvrige hadde regelmessige perioder. Gjennomsnittlig bruk av det aktuelle regimet var 9,3 år hos 1169 av 1191 brukere som besvarte spørsmålet om dette. Tabell 2 viser resultatet av logistisk regresjon. Blant de uavhengige faktorene viste røyking (røykfrihet) den mest uttalte sammenhengen med bruken av denne typen regime.

\section{Progesteronbrukerne}

Tabell 1 viser at gruppen som brukte progesteron alene skilte seg lite fra de premenopausale kvinnene som ikke brukte hormoner. Når det gjaldt menstruasjonsforhold, var gruppen heterogen: Hele 1076 progesteronbrukere ga rapport om uregelmessig eller opphørt menstruasjon, 40 om graviditet og 103 om amenorré etter fødsel, mens resten hadde regelmessige perioder. Gjennomsnittlig bruk av det aktuelle regimet var 2,9 år 
Tabell 1. Helserelaterte forhold etter indikatorer for menopausal status og bruk av hormonregimer. $\mathrm{N}=34284$.

\begin{tabular}{|c|c|c|c|c|c|c|c|c|c|c|c|c|}
\hline & & $\begin{array}{c}\text { Naturlig } \\
\text { menstrua- } \\
\text { sjon }\end{array}$ & Gravide & $\begin{array}{c}\text { Post } \\
\text { partum }\end{array}$ & \multicolumn{2}{|c|}{$\begin{array}{c}\text { Uansett menopausal } \\
\text { status }\end{array}$} & $\begin{array}{c}\text { Uregel- } \\
\text { messig } \\
\text { menstrua- } \\
\text { sjon }\end{array}$ & $\begin{array}{c}\text { Mulig } \\
\text { meno- } \\
\text { pause }\end{array}$ & $\begin{array}{l}\text { Meno- } \\
\text { pause } \\
\text { etter be- } \\
\text { handling }\end{array}$ & $\begin{array}{c}\text { Meno- } \\
\text { pause } \\
>6 \text { mnd. }\end{array}$ & \multirow{3}{*}{$\begin{array}{c}\text { Uansett } \\
\text { menopau- } \\
\text { sal status } \\
\text { Østrogen- } \\
\text { substitu- } \\
\text { sjon } \\
n=821\end{array}$} & \multirow{3}{*}{$\begin{array}{c}\text { Totalt } \\
N=34284\end{array}$} \\
\hline & & \multicolumn{3}{|c|}{$\begin{array}{c}\text { Ingen bruk av kvinnelige } \\
\text { kjønnshormoner }\end{array}$} & $\begin{array}{l}\text { Kombi- } \\
\text { nerte anti- } \\
\text { konseptiva }\end{array}$ & $\begin{array}{c}\text { Proge- } \\
\text { steron } \\
\text { alene }\end{array}$ & \multicolumn{4}{|c|}{ Ingen bruk av kvinnelige kjønnshormoner } & & \\
\hline & & $n=26917$ & $n=160$ & $n=185$ & $n=1191$ & $n=3225$ & $n=647$ & $n=274$ & $n=747$ & $n=105$ & & \\
\hline Gjennomsnitt: $\mathrm{H}$ & & 166,3 & 166,1 & 166,4 & 166,1 & 166,8 & 165,6 & 165,3 & 166,0 & 165,0 & 166,1 & 166,3 \\
\hline $\mathrm{KMI}, \mathrm{kg} / \mathrm{m}^{2}$ & & 25,1 & 26,4 & 24,9 & 25,0 & 24,9 & 25,8 & 26,1 & 25,7 & 25,6 & 25,0 & 25,1 \\
\hline Midjeomkrets & & 78,9 & 85,1 & 80,1 & 78,0 & 78,1 & 81,0 & 81,1 & 80,3 & 80,9 & 78,7 & 78,9 \\
\hline Alder, år & & 41,1 & 40,7 & 40,7 & 40,9 & 41,1 & 41,2 & 41,5 & 41,3 & 41,7 & 41,4 & 41,1 \\
\hline Prosent: Husarb & tigste yrke & 15,2 & 27,7 & 31,1 & 14,8 & 13,2 & 21,1 & 19,9 & 16,2 & 21,4 & 17,8 & 15,4 \\
\hline Høyere utdann & & 12,8 & 24,4 & 27,6 & 9,3 & 15,3 & 7,6 & 5,1 & 6,6 & 7,6 & 9,0 & 12,7 \\
\hline Gift & & 73,4 & 53,1 & 69,2 & 68,8 & 75,7 & 67,5 & 60,4 & 67,2 & 70,5 & 70,0 & 72,9 \\
\hline Egen sykdom & & 3,2 & - & 0,5 & 3,1 & 3,3 & 5,7 & 6,6 & 6,2 & 2,9 & 4,1 & 3,4 \\
\hline Hjertesykdom & ilien & 41,1 & 39,4 & 37,8 & 36,7 & 39,5 & 43,3 & 44,5 & 41,1 & 34,3 & 45,6 & 40,9 \\
\hline Muskel og led & ter $^{3}$ & 44,9 & 37,3 & 42,7 & 41,3 & 44,0 & 62,8 & 56,3 & 54,8 & 55,2 & 55,5 & 45,6 \\
\hline Brystsmerter i & akke & 4,2 & 2,5 & 1,6 & 3,0 & 3,5 & 10,2 & 7,8 & 7,3 & 8,8 & 8,1 & 4,4 \\
\hline Svært god gen & helse & 26,7 & 29,4 & 31,9 & 30,1 & 30,6 & 13,1 & 16,8 & 15,7 & 20,0 & 16,9 & 26,4 \\
\hline Ikke nervøs & -“- & 73,7 & 75,0 & 79,9 & 79,1 & 75,4 & 63,8 & 59,1 & 68,9 & 68,0 & 67,0 & 73,5 \\
\hline Ikke angst & -“- & 86,4 & 88,7 & 90,3 & 91,4 & 87,3 & 78,4 & 71,8 & 81,1 & 86,6 & 79,5 & 86,1 \\
\hline Ikke irritabel & -“- & 47,3 & 41,7 & 42,6 & 52,4 & 45,5 & 38,6 & 51,8 & 45,4 & 42,7 & 41,1 & 46,8 \\
\hline Ikke nedfor & -“- & 71,2 & 71,7 & 75,1 & 76,8 & 71,7 & 61,8 & 57,9 & 66,3 & 69,5 & 62,9 & 70,9 \\
\hline Røyker sigare & iglig & 37,7 & 21,9 & 14,1 & 21,2 & 35,9 & 50,9 & 56,9 & 49,7 & 52,4 & 50,2 & 37,7 \\
\hline Aldri røykt & & 32,5 & 36,9 & 44,3 & 41,7 & 34,7 & 27,0 & 17,9 & 23,8 & 31,4 & 24,4 & 32,5 \\
\hline Andel ex-røyk & & 24,3 & 30,0 & 34,1 & 29,1 & 24,3 & 17,6 & 19,7 & 23,8 & 13,3 & 20,7 & 24,2 \\
\hline Frukt/grønnsa & iglig & 72,0 & 81,3 & 77,8 & 74,6 & 73,8 & 65,5 & 64,6 & 68,0 & 68,6 & 67,7 & 72,4 \\
\hline Fisk daglig & & 5,0 & 6,2 & 0,5 & 4,0 & 4,9 & 5,9 & 9,5 & 7,1 & 10,5 & 6,6 & 5,2 \\
\hline Bare olje i ma & & 10,1 & 14,6 & 12,6 & 8,3 & 10,2 & 9,6 & 11,0 & 10,1 & 14,4 & 11,0 & 10,1 \\
\hline Mettet fett på & & 4,7 & 7,5 & 9,2 & 3,4 & 4,0 & 5,5 & 5,1 & 3,4 & 8,6 & 4,3 & 4,6 \\
\hline Ingen hard mo & & 31,5 & 40,4 & 42,0 & 31,4 & 27,9 & 37,2 & 41,7 & 35,5 & 43,8 & 33,9 & 31,6 \\
\hline Stillesittende & i fritiden & 19,5 & 18,6 & 20,4 & 20,8 & 17,3 & 24,4 & 23,6 & 21,5 & 30,9 & 21,9 & 19,6 \\
\hline
\end{tabular}

${ }^{1}$ Universitet eller høyskole 4 år eller mer.

${ }^{2}$ Gjennomgått hjerteinfarkt eller hjerneslag, angina pectoris, diabetes eller bruker medisin mot høyt blodtrykk.

${ }^{3}$ Smerter eller stivhet i muskler og ledd minst 3 måneder siste år.

${ }^{4}$ Smør eller hard margarin på brød.

${ }^{5}$ Ikke regelmessig hard mosjon (svett eller andpusten) så ofte som ukentlig siste år.

hos 3080 av 3225 som svarte på dette. Logistisk regresjon viste at progesteronbruk var knyttet til noe høyere utdanning, sett i forhold til kvinner som ikke brukte hormoner (Tabell 3).

\section{Ostrogenbrukerne}

Tabell 1 viser at de som brukte østrogensubstitusjon, $2,4 \%$ av materialet totalt, skilte seg lite ut fra kvinnene med opphørt eller uregelmessig menstruasjon. KMI og midjeomkrets var imidlertid lavere hos hormonbrukerne $(p<0,001)$. Blant østrogenbrukerne rapporterte 353 om regelmessig, spontan menstruasjon, en om graviditet, 30 om amenorrè etter fødsel, 92 om sikker menopause, 42 om mulig menopause, 220 om menopause etter operasjon og $75 \mathrm{om}$ helt uregelmessige blødninger. Gjennomsnittlig bruk av nåværende regime var 2,9 år hos de 799 av 821 kvinner som svarte på spørsmålet.
Tabell 4 viser at bare alder og overvekt (negativt) var forbundet med bruk av østrogen blant antatt postog perimenopausale kvinner. Separate regresjonsanalyser av kvinner som møtte i 1997, 1998 og 1999 ga svært like resultater. Tabell 5 viser at østrogenbruk i materialet som helhet var forbundet med daglig røyking, alder, utdanning (negativt) og helseplager.

\section{Faktorer forbundet med tidlig ovarialsvikt}

Tabell 1 viser at gravide og kvinner som nylig hadde født var kjennetegnet ved høy utdanning, lite helseplager, utmerket generell helse og lite røyking, mens alle gruppene med opphørt menstruasjon, uregelmessige blødninger eller østrogenbruk lå på de motsatte ytterlighetene. Tabell 6 viser at særlig røyking, og også en rekke av de uavhengige variablene, var signifikant forbundet med antatt post- eller perimenopausal status som avhengig variabel. 
Tabell 2. Faktorer knyttet til bruk av kombinerte antikonseptiva blant ikke gravide, premenopausale kvinner med spontan menstruasjon. $\mathrm{N}=28108$, hvorav 1191 brukte kombinerte antikonseptiva.

\begin{tabular}{lcc}
\hline & OR $(\operatorname{Exp}(\mathrm{B}))$ & $95 \% \mathrm{KI}$ \\
\hline Alder, år & 0,78 & $0,73-0,83$ \\
Utdanning $^{1}$ & 0,78 & $0,69-0,88$ \\
Daglig røyking & 0,41 & $0,36-0,48$ \\
Koronar hjertesykdom i familien $^{\text {Brystsmerter ved anstrengelse }}$ & 0,85 & $0,75-0,96$ \\
\hline
\end{tabular}

${ }^{1}$ Videregående skole, allmennfag eller høyere utdanning, versus kortere allmennutdanning.

Bare faktorer med OR signifikant forskjellig fra 1 er presentert i tabellen.

Tabell 3. Faktorer knyttet til bruk av progesteron alene blant ikke gravide, premenopausale kvinner med spontan menstruasjon. $\mathrm{N}=30$ 142, hvorav 3225 brukte progesteron alene.

\begin{tabular}{lcc}
\hline & OR $(\operatorname{Exp}(\mathrm{B}))$ & $95 \% \mathrm{KI}$ \\
\hline Utdanning $^{1}$ & 1,29 & $1,19-1,39$ \\
Overvekt $^{2}$ & 0,88 & $0,81-0,96$ \\
Hard trim i fritiden & 1,11 & $1,02-1,21$ \\
Husarbeid hovedyrke & 0,89 & $0,79-0,99$ \\
\hline
\end{tabular}

${ }^{1}$ Videregående skole, allmennfag, eller høyere utdanning versus kortere allmennutdanning

${ }^{2} \mathrm{KMI}$ lik eller over $27 \mathrm{~kg} / \mathrm{m}^{2}$

Bare faktorer med OR signifikant forskjellig fra 1 er presentert i tabellen.

Tabell 4. Faktorer knyttet til bruk av østrogensubstitusjon blant antatt post- og perimenopausale kvinner. $\mathrm{N}=2594$, hvorav 821 østrogenbrukere.

\begin{tabular}{lcc}
\hline & OR (Exp (B)) & $95 \%$ KI \\
\hline Alder, år & 1,15 & $1,05-1,25$ \\
Overvekt $^{1}$ & 0,71 & $0,59-0,86$ \\
\hline
\end{tabular}

${ }^{1} \mathrm{KMI}$ lik eller over $27 \mathrm{~kg} / \mathrm{m}^{2}$

Bare faktorer med OR signifikant forskjellig fra 1 er presentert i tabellen.

Tabell 5. Faktorer knyttet til bruk av østrogensubstitusjon blant samtlige kvinner i materialet. $\mathrm{N}=34284$, hvorav 821 østrogenbrukere.

\begin{tabular}{lcc}
\hline & OR (Exp (B)) & $95 \%$ KI \\
\hline Alder, år & 1,37 & $1,28-1,47$ \\
Utdanning $^{1}$ & 0,80 & $0,69-0,93$ \\
Daglig røyking & 1,51 & $1,31-1,74$ \\
Muskel/leddsmerter & 1,24 & $1,07-1,44$ \\
Brystsmerter ved anstrengelse & 1,47 & $1,13-1,93$ \\
God/svært god generell helse & 0,65 & $0,55-0,78$ \\
\hline
\end{tabular}

${ }^{1}$ Videregående skole, allmennfag eller høyere utdanning, versus kortere allmennutdanning

Bare faktorer med OR signifikant forskjellig fra 1 er presentert i tabellen.
Tabell 6. Faktorer knyttet til post- eller perimenopausal status. $\mathrm{N}=34$ 284, hvorav 2594 med antatt sviktende ovarialfunksjon.

\begin{tabular}{|c|c|c|}
\hline & OR $(\operatorname{Exp}(B))$ & $95 \% \mathrm{KI}$ \\
\hline Alder, år & 1,27 & $1,22-1,32$ \\
\hline Utdanning $^{1}$ & 0,75 & $0,68-0,82$ \\
\hline Daglig røyking & 1,57 & $1,44-1,71$ \\
\hline Egen sykdom $^{2}$ & 1,33 & $1,10-1,61$ \\
\hline Overvekt $^{3}$ & 1,18 & $1,08-1,29$ \\
\hline Muskel/ leddsmerter & 1,31 & $1,20-1,43$ \\
\hline Brystsmerter ved anstrengelse & 1,43 & $1,22-1,68$ \\
\hline God/svært god generell helse & 0,64 & $0,58-0,71$ \\
\hline Depresjon & 1,19 & $1,02-1,40$ \\
\hline
\end{tabular}

${ }^{1}$ Videregående skole, allmennfag eller høyere utdanning, versus kortere allmennutdanning

${ }^{2}$ Hjerte- og karsykdom, hypertensjonsbehandling eller diabetes mellitus

${ }^{3} \mathrm{KMI}$ lik eller over $27 \mathrm{~kg} / \mathrm{m}^{2}$

Bare faktorer med OR signifikant forskjellig fra 1 er presentert i tabellen.

\section{DISKUSJON}

40-åringsprogrammet var primært et tilbud til den enkelte om forebyggende helseundersøkelse. Spørreskjemaet og undersøkelsen for øvrig var derfor ikke skreddersydd for å belyse seleksjonen til bruk av hormoner. Noen vil savne spørsmål om grunnene til hormonbruk, om hetetokter og om andre plager som forbindes med overgangsalderen. Den selvrapporterte medikasjonen ble ikke kontrollert mot pakning eller legejournal. En kanadisk studie fant bare $43 \%$ samsvar mellom intervju og journaler (23). Det er imidlertid grunn til å tro at samsvaret er større i dette norske materialet fordi de kanadiske kvinnene var noe eldre, 3079 år, og fordi de norske 40 -åringene fylte ut skjemaet mens de var hjemme og hadde pakningen for hånden.

\section{Brukerne av kombinerte antikonseptiva - et sunt utvalg}

Resultatene viser at 40-åringene som brukte kombinerte antikonseptiva for en stor del var røykfrie og hadde god helse, til tross for lavere utdanning enn andre premenopausale grupper av kvinner. Gjennomsnittlig bruk av det aktuelle regimet var lang, drøyt 10 år, noe som kan tyde på at det har skjedd et selektivt frafall fra bruken med alderen. I så fall er dette i tråd med det som er blir anbefalt (14). Videre ser det ut til at utviklingen har gått i riktig retning de siste årene (6). Man kan imidlertid ikke se bort fra at hormontilskuddet i seg selv kan ha gunstige effekter hos noen av disse litt eldre brukerne. Det kan videre hevdes at daglig røyking hos $22 \%$ er en alt for høy andel. Antagelig står vi her overfor en gruppe av sterkt nikotinavhengige som trenger mer hjelp enn generelle råd for å klare å slutte å røyke. 


\section{Progesteronbrukerne}

Valget av å bruke et progesteronregime kan ha bakgrunn i kontraindikasjoner for bruk av kombinasjonspille, blødningsforstyrrelser og ønske om ikke å bruke østrogen. Trolig er progesteronbrukerne en svært heterogen gruppe. Sammenlignet med premenopausale kvinner som ikke bruker noe hormonregime, står de fram som litt høyere utdannet og litt slankere, men var alt $i$ alt svært like.

\section{Ostrogenbrukerne - en risikogruppe?}

Brukerne av østrogen var litt slankere enn andre kvinner som antas å være post- eller perimenopausale. En stor, kontrollert amerikansk studie viste ingen slankende effekt av østrogensubstitusjon på midjeomkrets eller vekt (24). Dette tilsier at østrogenbrukerne var en "sunn seleksjon" på dette punktet. Det finnes imidlertid også holdepunkt for at østrogen påvirker leptin, som igjen påvirker kroppsfett, og på den måten motvirker vektøkning hos østrogenbrukere (25). Likevel er det liten støtte i dette materialet for hypotesen om "sunn seleksjon" til østrogenbruk. Sammenlignes østrogenbrukerne med det store flertall av jevnaldrende, står de - i likhet med andre grupper med opphørt eller uregelmessig menstruasjon - fram som en gruppe med svært høye andeler røykere og klart flere helseplager.

Det er vanskelig å ta stilling til om bruken av østrogen var i tråd med gjeldende anbefalinger. Mange 40-åringer brukte ikke hormoner til tross for tidlig opphør av menstruasjonen. Vi vet ikke om de har fått informasjon og veiledning fra sine leger, noe retningslinjene sier at de burde ha fått (8). Og det kan være gode grunner, sett fra kvinnenes side, til ikke å ville benytte seg av østrogenbehandling (26). Resul tatetene tyder imidlertid ikke på at røykere og andre kvinner med risikofaktorer for hjertesykdom er blitt frarådet hormoner, eller selv har vært spesielt redde for å bruke slike midler. Dette er i tråd med anbefalingene som ble gitt fram til $1998(8,14,16)$. I 1998 ble bruk av østrogen frarådet hvis hensikten var å forebygge hjerte- og karsykdom (17-19). Her i Norge har denne indikasjonen stått for bare en svært liten del, 5\%, av østrogenbruken (13). Derfor er det ikke overraskende at de endrede signalene i 1998 ikke har latt seg spore i 40åringsdataene.

\section{Fertilitet på den ene siden - og tobakk på den andre?}

Gravide, kvinner som nylig hadde født og de som brukte kombinerte antikonseptiva sto fram som friske utvalg med lav prevalens av røyking. De som svarte at menstruasjonen hadde sluttet, var uregelmessig eller som brukte østrogen, sto fram som en motpol til disse. Man aner en sårbar gruppe med lav utdanning, økt risiko for kroniske sykdommer og overhyppighet av en rekke plager. Hvilken rolle spiller røykingen i dette virkning, årsak eller begge deler? En tverrsnittsstudie er ikke egnet til å belyse årsaker. Det er imidlertid kjent fra andre studier at tobakk virker antiøstrogent og bidrar til å fremskynde menopausen $(27,28)$. Uansett årsaksforhold er røyking en ekstra belastning når ovarialfunksjonen ligger lavt, og det er gode argumenter for at tilbud om hjelp til å slutte å røyke bør inngå i medisinsk veiledning til kvinner med tegn til tidlig overgangsalder.

\section{LITTERATUR}

1. Hannaford P. Cardiovascular events associated with different combined oral contraceptives: a review of current data. Drug Saf 2000; 22 (5): 361-71.

2. Hemminki E, Malin M, Topo P. Selection of postmenopausal therapy by women's characteristics. $J$ Clin Epidemiol 1993: 46: 211-9.

3. Vessey MP, Villard-Mackintosh L, McPherson K, Yeates D. Mortality among oral contraceptive users: 20year follow-up of women in a cohort study. BMJ 1989; 299: 1487-91.

4. Cardiovascular disease and use of oral and injectable progestogen-only contraceptives and combined injectable contraceptives. Results of an international, multicenter, case-control study. World Health Organization Collaborative Study of Cardiovascular Disease and Steroid Hormone Contraception. Contraception 1998; 57 (5): 315-24.

5. Antikonsepsjon. Workshop 31. mars - 1. april 1993. Nytt fra Statens legemiddelkontroll nr. 5. Oslo: Statens legemiddelkontroll, 1993.

6. Graff-Iversen S, Tverdal A, Stensvold I. Cardiovascular risk factors in Norwegian women using oral contraceptives: Result from a cardiovascular health screening 1985-88. Contraception 1996; 53: 337-44.

7. NOU 2000:16. Tobakkindustriens erstatningsansvar. Oslo: Statens forvaltningstjeneste, 2000.

8. Behandling med östrogen. SBU-rapport nr. 131. Stockholm: SBU, 1996.

9. Persson I, Bergkvist L, Lindgren C, Yuen J. Hormone replacement therapy and major risk factors for reproductive cancers, osteoporosis, and cardiovacsular disease: evidence of confounding by exposure characteristics. J Clin Epidemiol 1997; 50 (5): 611-8. 
10. Mattews KA, Kuller LH, Wing RR, et al. Prior to use of estrogen replacement therapy, are users healthier than non-users? Am J Epidemiol 1996; 143: 971-8.

11. Sturgeon SR, Schairer C, Brinton LA, Pearson T, Hoover RN. Evidence of a healthy estrogen user survivor effect. Epidemiology 1995; 6: 277-231.

12. Graff-Iversen S, Stensvold I, Lund-Larsen PG, Nodarse LO, Tverdal A, Urdal P. Serum lipids in postmenopausal or perimenopausal women using estrogen alone, estrogen with levonorgestrel, or estrogen with norethisterone, compared with non-users: Results from a cross-sectional study in two Norwegian counties 1985-88. J Clin Epidemiol 1998; 51 (12): 1311-6.

13. Søgaard AJ, Fønnebø V, Magnus J, Tollan A. Hormonsubstitusjon blant norske kvinner. Selvrapportert bruk og omsetning av østrogenholdige preparater. Tidsskr Nor Laegeforen 1998; 118: 590-5.

14. Veierød AM (red.). Norsk legemiddelhåndbok 1998-99 for helsepersonell. Norsk legemiddelhåndbok I/S 1998. Aurskog: 1997.

15. Hunskår S, Hannestad YS, Backe B, Matheson I. Holdningsendring til forskriving av østrogen blant norske allmennpraktikere 1990-92. Tidsskr Nor Laegeforen 1994; 114: 2095-8.

16. Nesheim BI. Østrogen - bra for hjertet (?) Tidsskr Nor Loegeforen 1994; 114: 2094.

17. Hulley S, Grady D, Bush T, et al. Randomized trial of estrogen plus progestin for secondary prevention of coronary heart disease in postmenopausal women. JAMA 1998; 280: 605-13.

18. Herrington DM. The HERS trial results: paradigms lost? Heart and Estrogen/Progestin Replacement Study. Ann Intern Med 1999; 131: 463-6.

19. Barrett-Connor E, Stuenkel C. Hormones and heart disease in women: Heart and Estrogen/Progestin Replacement Study in perspective. J Clin Endocrinol Metab 1999; 84: 1848-53.

20. Bjartveit K, Foss PO, Gjervig T, Lund-Larsen PG. The cardiovascular disease study in Norwegian counties. Background and organization. Acta Med Scand 1985; Suppl. 634: 1-70.

21. Bjartveit K (red.). Håndbok for hjerte- og karundersøkelsen. Oslo: Statens helseundersøkelser, 1987.

22. Norusis MJ/SPSS Inc. SPSS for Windows Advanced Statistics Release 6.0. Chicago: SPSS Inc, 1990.13.

23. Jain MG, Rohan TE, Howe GR. Agreement of self-reported use of menopausal replacement therapy with physicians reports. Epidemiology 1999; 10: 260-3.

24. The writing group for the PEPI trial. Effects of estrogen or estrogen/progestin regimens on heart disease risk factors in postmenopausal women. JAMA 1995; 273: 199-208.

25. Di Carlo C, Tommaselli GA, Pisano G, Nasti A, Rossi V, Palomba S, Nappi C. Serum leptin levels in postmenopausal women: effects of transdermal hormone replacement therapy. Menopause 2000; 7 (1): 36-41.

26. Guillemin MN. Managing menopause: a critical feminist engagement. Scand J Publ Health 1999; 27: 273-8.

27. Bromberger JT, Mattews KA, Kuller LH, Wing RR, Meilahn EN, Platinga P. Prospective study of the determinants of age at menopause. Am J Epidemiol 1997; 145: 124-33.

28. Midgette AS, Baron JA. Cigarette smoking and the risk of natural menopause. Epidemiology 1990; 1: 474-80. 